\title{
Pemerhatian Arus Ionosfera semasa Suar Suria Kuat Menggunakan Data Magnetometer Dasar
}

(Observation of Ionospheric Current during Strong Solar Flare Using Ground Based Magnetometer)

\author{
N.M.N. ANNADURAI, N.S.A. HAMID* \& A. YOSHIKAWA
}

\begin{abstract}
ABSTRAK
Suar suria merujuk kepada aktiviti matahari yang ditafsirkan sebagai cahaya terang yang meletus secara tiba-tiba dari permukaan matahari. Ia mampu menjejaskan sistem ionosfera bumi justeru mengganggu mana-mana arus yang mengalir di lapisan tersebut. Kejadian ini dapat diperhatikan melalui pemerhatian data magnetometer yang dicerap di bumi. Kesan umum suar suria adalah peningkatan kekonduksian ionosfera seterusnya meningkatkan keamatan arus namun didapati terdapat beberapa suar suria mampu memberikan kesan sebaliknya. Terdapat kajian yang melaporkan bahawa satu suar suria mampu meningkatkan keamatan arus di sesetengah kawasan dan pengurangan keamatan pada kawasan yang lain. Kajian lepas pula lebih tertumpu kepada kesan suar suria pada kawasan sektor tertentu atau setempat. Walau bagaimanapun, kajian ini mengambil pendekatan untuk menganalisis sifat suar suria dan kesannya menggunakan taburan data yang lebih meluas iaitu melibatkan stesen magnetometer yang dipasang di lima sektor. Data yang digunakan adalah daripada jaringan Magnetic Data Acquisition System/Circum Pan Magnetometer Network Pacific (MAGDAS/CPMN) dan suar suria dikenal pasti melalui data fluks sinar-X yang dicerap daripada satelit Geostationary Operational Environmental Satellite 15 (GOES 15). Keputusan kajian menunjukkan kesan suar suria yang tidak pernah ditemui sebelum ini iaitu pengurangan keamatan arus pada semua data cerapan di khatulistiwa magnetik dan punca yang dicadangkan adalah kewujudan arus elektrojet berlawanan. Selain itu, keputusan kajian turut mendapati bahawa suar suria tersebut berlaku pada fasa pemulihan ribut geomagnet semasa soltis Jun dalam fasa suria menaik.
\end{abstract}

Kata kunci: Arus ionosfera; medan geomagnet; suar suria

\section{ABSTRACT}

Solar flare is referring to sun's activity define as sudden intense bright light coming from its surface. It can immediately affect earth's ionosphere system thus perturb any currents flowing in the layer. The activity can be monitored using ground based magnetometer data. Regularly, the event will enhance the ionospheric conductivity thus increase the magnitude of the currents however the opposite effect has been reported recently. There were studies reported that a solar flare is capable to increase current intensity at some location and reduces it at other location. Previous study were focused on solar flare effect at some particular area sector or locally. Therefore, our approach is to analyze solar flare feature and its effect using extensive magnetometer data distribution which involve stations from five sectors. Data are obtained from Magnetic Data Acquisition System/Circum-pan Pacific Magnetometer Network (MAGDAS/CPMN) and solar flare is identified using Geostationary Operational Environmental Satellite 15 (GOES 15) X-ray flux data. Our study discovered a new effect of solar flare which is reduction of current intensity at all magnetic equator data and the proposed factor is existence of counter electrojet current. Apart from that, we also found that this solar flare occurred on geomagnetic storm recovery phase during June solstice in inclining phase of solar cycle.

Keywords: Geomagnetic field; ionospheric current; solar flare

\section{PENGENALAN}

Atmosfera bumi terdiri daripada beberapa lapisan bermula daripada lapisan troposfera sehingga ke termosfera. Terdapat pelbagai kajian telah dijalankan untuk menyelidik lapisan atmosfera ini (Shojanoori et al 2016; Simon et al. 2017). Namun begitu, penyelidikan ini memfokuskan pada lapisan ionosfera. Lapisan ini mempunyai komposisi atom teruja paling tinggi berbanding lapisan lain. Menariknya di lapisan ini adalah terdapat satu jalur arus berkeamatan tinggi di lapisan E yang dikenali sebagai sebagai arus elektrojet khatulistiwa, EEJ (Chapman 1951). Arus ini terhad di latitud $\pm 3^{\circ}$ bumi dan mengalir ke arah timur. Selain daripada arus EEJ, terdapat juga arus yang mengalir secara lawan jam di hemisfera utara bumi dan sebaliknya di hemisfera selatan yang dikenali sebagai arus suria senyap, Sq. Pelbagai kajian telah dijalankan terhadap arus ini termasuk kebergantungannya terhadap kitaran suria (Hamid et al. 2013), longitud (Ismail et al. 2017; Rabiu et al. 2017), latitud (Hamid et al. 2017) dan musim (Hamid et al. 2015). Antara peralatan yang telah digunakan untuk pemerhatian arus tersebut adalah satelit (Thomas et al. 2016), roket (Omwumechili 1997) dan digisonde (Ning \& 
Li 2014) serta magnetometer dasar (Okeke 2006). Kajian kali ini tertumpu kepada penggunanan data magnetometer dasar yang terletak di sepanjang kawasan khatulistiwa magnetik bumi. Aktiviti matahari yang berlaku seperti suar suria turut diketahui memberi impak kepada arus-arus di ionosfera ini. Kesan umum suar suria adalah peningkatan nilai arus keseluruhan di khatulistiwa geomagnetik yang biasanya diperhatikan melalui bacaan komponen utara geomagnet, H (Rastogi et al. 2003). Namun begitu, adakalanya berlaku fenomena suar suria yang mampu merendahkan bacaan arus. Keadaan ini pernah dilaporkan berlaku pada waktu pagi atau petang (Rastogi et al. 1975; Sastri 1975; Yamazaki et al. 2009). Namun, ia amat janggal berlaku pada waktu tengah hari dengan Rastogi (1997) mengatakan bahawa kebarangkalian berlakunya pengurangan bacaan ketika waktu tengah hari di kawasan India adalah hanya satu peratus sahaja dan berlaku pada fasa awal ribut geomagnet. Menggunakan data geomagnet daripada jaringan Circum-pan Pacific Magnetomer Network (CPMN), Yamazaki et al. (2009) telah mengkaji kesan suar suria pada kitaran suria ke 23. Beliau telah merekodkan dua kejadian pengurangan komponen geomagnetik utara iaitu pada 18 Jun 2000 and 3 Julai 2002. Hal ini adalah pada waktu tengah hari dan berlaku ketika fasa suria maksima. Beberapa tahun selepas itu, Rastogi et al. (2013) mengkaji semula fenomena tersebut dengan penambahan stesen magnetometer daripada jaringan International Real-time Magnetic Observatory (INTERMAGNET), Indian Institute of Geomagnetism (IIG) dan beberapa stesen tunggal. Keputusan kajian mereka mendapati bahawa pengurangan keamatan arus EEJ turut berlaku pada waktu suria maksima dan Soltis Jun. Informasi terbaharu yang direkodkan oleh Yamazaki dan Maute (2016) di dalam kertas kajian mereka mengatakan bahawa kejadian pengurangan bacaan arus pada komponen utara geomagnet yang dikaji sehingga kitaran suria ke-23 masih menjadi tanda tanya sehingga kini. Keputusan kajian terdahulu ini turut melaporkan sesuatu suar suria boleh menyebabkan peningkatan arus di suatu kawasan dan pengurungan arus di kawasan yang lain (Yamazaki et al. 2009). Terdapat laporan kajian lepas turut tertumpu pada data satu stesen atau kawasan tertentu sahaja seperti kawasan India (Rastogi 1997). Malah, kekurangan stesen pemerhatian pada khatulistiwa geomagnetik juga menghadkan hasil cerapan. Oleh itu, kajian kali ini adalah lebih meluas dengan analisis yang dijalankan melibatkan data cerapan di kebanyakan khatulistiwa geomagnetik daripada lima sektor berbeza.

\section{DATA DAN METOD}

Lapan stesen pencerapan telah dipilih untuk kajian ini. Kesemua stesen magnetometer adalah daripada jaringan Magnetic Data Acqusition System (MAGDAS) yang terletak di kawasan khatulistiwa magnetik. Rajah 1 menunjukkan taburan lokasi stesen tersebut. Simbol bulat merah menandakan stesen di kawasan khatulistiwa geomagnetik dan simbol bulat biru menandakan stesen di luar khatulistiwa geomagnetik. Pemilihan stesen pada longitud yang hampir sama di luar khatulistiwa geomagnetik adalah untuk mengkaji arus Sq. Hal ini adalah kerana bacaan komponen $\mathrm{H}$ di khatulistiwa geomagnetik melambangkan arus keseluruhan $(\mathrm{EEJ}+\mathrm{Sq})$ dan bacaan komponen $\mathrm{H}$ di luar khatulistiwa geomagnetik adalah arus Sq. Maklumat stesenini termasuk koordinatnya disenaraikan dalam Jadual 1. Kajian dimulakan dengan menganalisis suar suria kuat iaitu suar suria kelas $\mathrm{X}$ yang berlaku sepanjang tahun 2008 sehingga 2015 iaitu sebahagian fasa suria ke-24. Tempoh fasa suria ke-24 dipilih adalah kerana kajian lepas mengfokuskan suar suria pada fasa ke-23 dan sebelumnya. Selain itu, hanya suar suria kelas $\mathrm{X}$ yang dititik berat kerana laporan penyelidik lepas menunjukkan bahawa suar suria daripada kelas itu sahaja mampu menyebabkan pengurangan keamatan komponen $\mathrm{H}$ di khatulistiwa geomagnetik bumi. Apabila tarikh yang sesuai telah didapati, data fluks sinar-X yang direkodkan daripada satelit GOES 15 diplot untuk pemerhatian yang lebih tepat mengenai suar suria yang berlaku. Setelah itu, variasi fluks sinar-X akan dibandingkan dengan komponen $\mathrm{H}$ daripada data geomagent. Gangguan yang disebabkan oleh suar suria dikira dengan cara komponen $\mathrm{H}$ pada waktu puncak suar suria ditolak dengan nilai komponen $\mathrm{H}$ pada waktu permulaan kesan suar suria.

\section{KEPUTUSAN DAN PERBINCANGAN}

Sebanyak 47 peristiwa suar suria telah dikenal pasti. Namun begitu, hanya satu sahaja yang didapati unik dan suar suria ini telah menyebabkan pengurangan keamatan komponen $\mathrm{H}$ pada semua data di stesen khatulistiwa magnetik iaitu pada 9 Ogos 2011. Plot fluks sinar-X dan data komponen

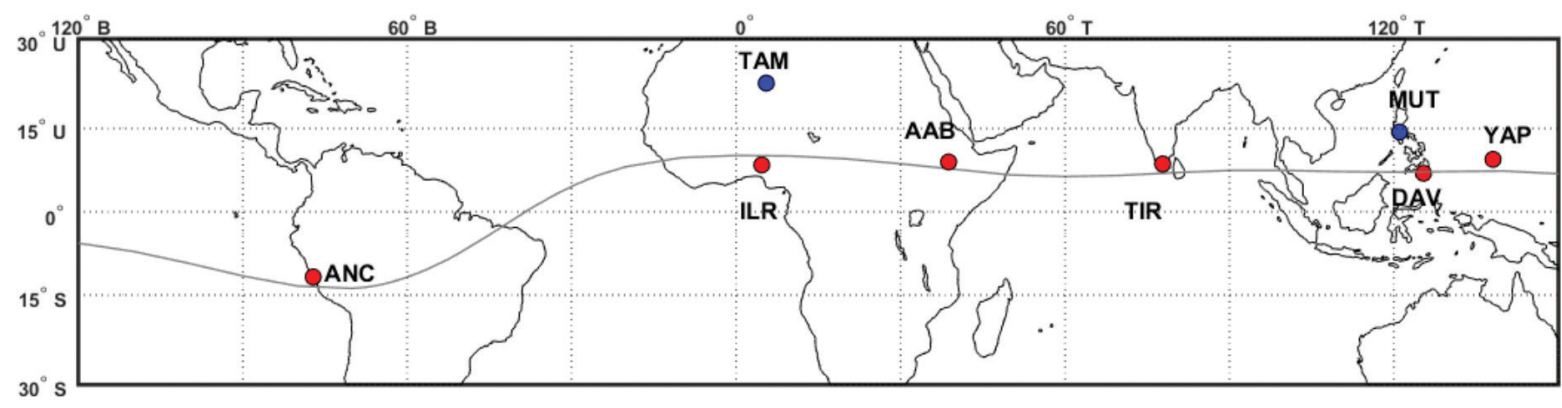

RAJAH 1. Taburan stesen yang digunakan 
JADUAL 1. Maklumat lokasi, kod, koordinat geografi dan geomagnet stesen

\begin{tabular}{lllcccc}
\hline \multirow{2}{*}{ Lokasi } & \multirow{2}{*}{ Nama stesen } & \multirow{2}{*}{ Kod } & \multicolumn{2}{c}{ Geografi } & \multicolumn{2}{c}{ Geomagnet } \\
\cline { 4 - 7 } & & & Lat. $\left({ }^{\circ}\right)$ & Lon. $\left({ }^{\circ}\right)$ & Lat. $\left({ }^{\circ}\right)$ & Lon. $\left({ }^{\circ}\right)$ \\
\hline \multirow{2}{*}{ Afrika } & Ilorin & ILR & 8.50 & 4.68 & -1.82 & 76.80 \\
& Tamanrasset & TAM & 22.8 & 5.5 & 25.4 & 80.6 \\
\multirow{4}{*}{ India } & Adis Ababa & AAB & 9.04 & 38.77 & 0.18 & 110.47 \\
Asia Tenggara & Tirunelveli & TIR & 8.70 & 77.80 & 0.21 & 149.30 \\
& Davao & DAV & 7.00 & 125.40 & -1.02 & 196.54 \\
& Muntinlupa & MUT & 14.37 & 121.02 & 6.79 & 192.25 \\
Amerika Selatan & PulauYap & YAP & 9.50 & 138.08 & 1.49 & 209.06 \\
& Ancon & ANC & -11.77 & -77.15 & 0.77 & 354.33 \\
\hline
\end{tabular}

$\mathrm{H}$ adalah ditunjukkan pada Rajah 2. Panel atas iaitu plot 2(a) menunjukkan berlakunya suar suria kelas X6.9 yang berpuncak pada 0805 UT yang diterjemahkan daripada bacaan fluks sinar-X. Hampir sejurus selepas itu, berlaku gangguan kepada nilai komponen $\mathrm{H}$ daripada setiap stesen yang dicerap seperti yang diplot pada Rajah 2(b). Garis merah melintang merujuk kepada waktu permulaan suar suria, anak panah hitam pada rajah tersebut menunjukkan waktu puncak suar suria manakala anak panah merah menunjukkan waktu kesan (pengurangan) maksimum ia terhadap data cerapan. Rajah 3 pula adalah gambaran yang diperbesarkan daripada Rajah 2 dengan kesan suar suria tersebut dapat dilihat dengan lebih teliti. Rajah 3(a) adalah data dari stesen di khatulistiwa magnetik dan 3(b) adalah data untuk stesen di luar khatulistiwa magnetik. Lokasi stesen mengikut waktu tempatan ketika suar suria seperti yang digambarkan dalam Rajah 4. Bahagian atas yang berwarna putih melambangkan bahagian bumi yang menghadap cahaya matahari dan sebaliknya untuk yang berwarna hitam. Nilai pengurangan yang berlaku kepada data komponen H direkodkan pada Jadual 2. Berdasarkan jadual tersebut, pengurangan keamatan komponen $\mathrm{H}$ dapat dikesan pada semua stesen yang menghadap matahari dan jelas bahawa hanya sedikit sahaja kesan suar suria berlaku pada data di stesen Ancon (ANC) iaitu 0.56nT. Data di stesen Ilorin (ILR) adalah paling tinggi dengan pengurangan sebanyak $-35.83 \mathrm{nT}$ dan diikuti oleh stesen Addis Ababa (AAB) sebanyak -26.41nT, Tirunelveli (TIR) -17.42nT, Davao (DAV) -16.40nT dan stesen Pulau Yap (YAP) -11.03nT. Buat kali pertamanya pengurangan keamatan komponen $\mathrm{H}$ pada data yang dicerap di seluruh stesen yang terletak di longitud khatulistiwa magnetik berbeza telah berjaya dianalisis dan direkodkan. Stesen ANC kurang mendapat kesan suar suria berbanding stesen

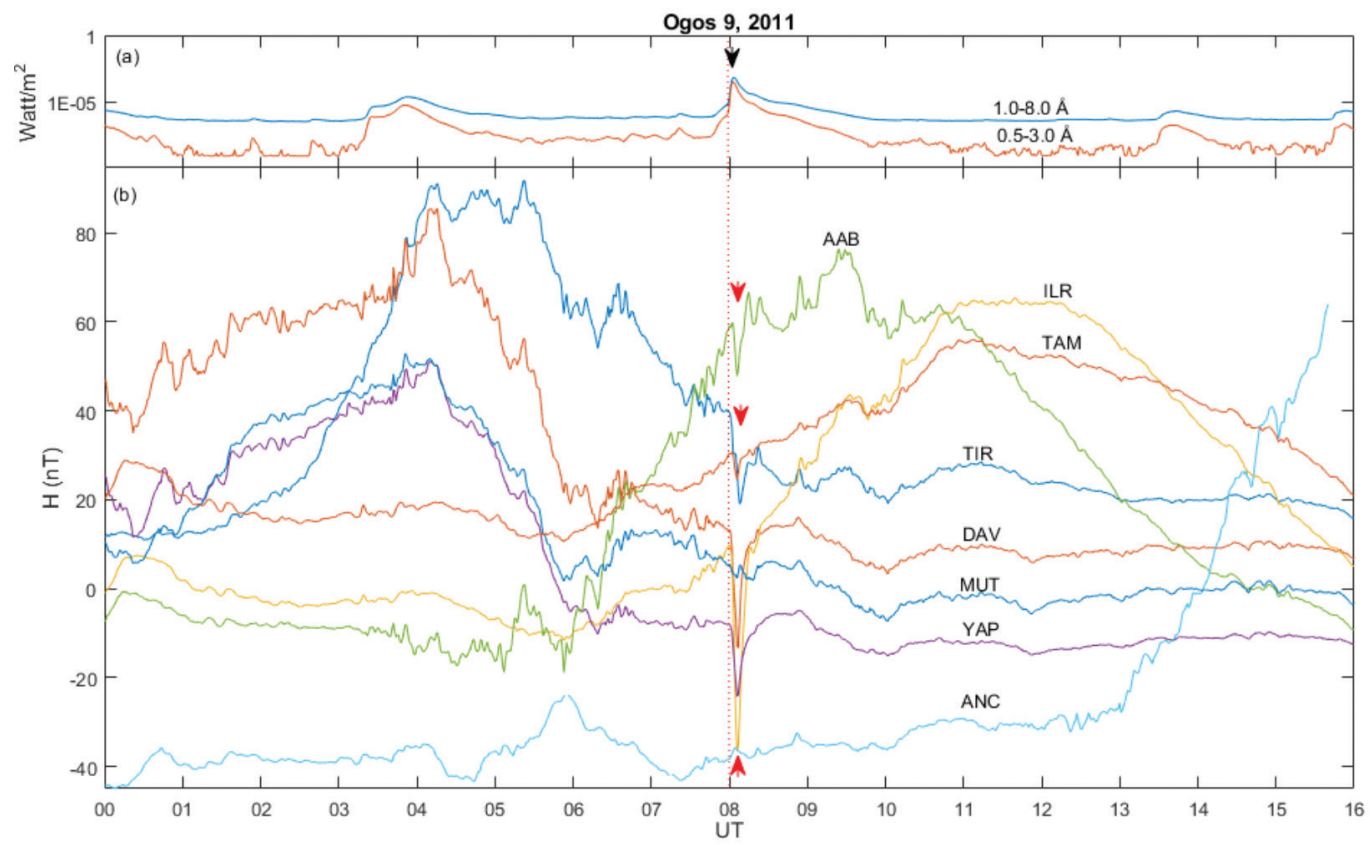

RAJAH 2. (a) Variasi data fluks sinar-X GOES 15 dan (b) bacaan komponen H pada stesen-stesen pencerapan. Anak panah hitam menunjukkan waktu puncak suar suria manakala anak panah merah menunjukkan waktu kesan maksimum (pengurangan) ia terhadap dari data cerapan. Garis terputus menegak pula menunjukkan waktu mula suar suria 

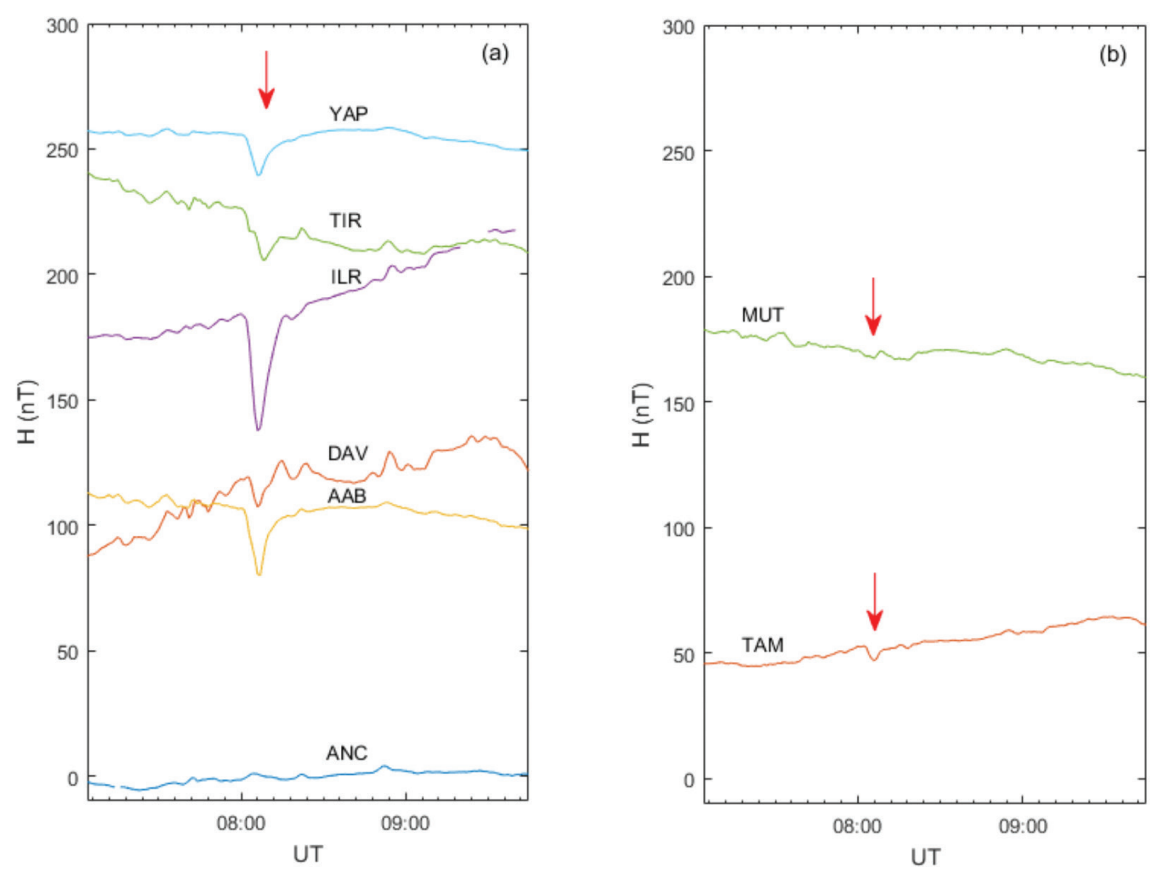

RAJAH 3. Bacaan komponen H di stesen (a) khatulistiwa geomagnetik dan (b) luar khatulistiwa geomagnetik. Anak panah menunjukkan kesan maksimum suar suria kepada komponen $\mathrm{H}$

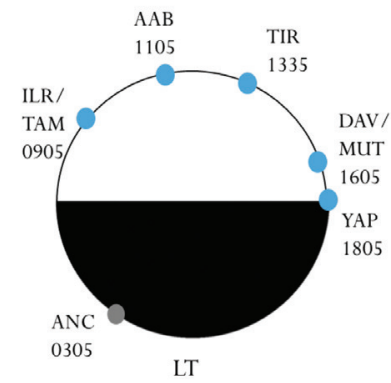

RAJAH 4. Lokasi stesen ketika berlakunya suar suria. Bulatan separa berwarna putih menunjukkan bahagian bumi yang menghadap matahari dan hitam adalah kawasan yang tidak menghadap matahari
JADUAL 2. Perbezaan nilai komponen $\mathrm{H}$ yang disebabkan oleh suar suria

\begin{tabular}{cc}
\hline Stesen & $\begin{array}{c}\text { Perbezaan nilai komponen } \mathrm{H} \\
(\mathrm{nT})\end{array}$ \\
\hline AAB & -26.41 \\
ANC & 0.56 \\
DAV & -16.40 \\
MUT & 1.41 \\
ILR & -35.83 \\
TAM & -2.5 \\
TIR & -17.42 \\
YAP & -11.03 \\
\hline
\end{tabular}

mengalir ke arah barat dan ia bertentangan dengan arah EEJ yang mengalir ke arah timur. Dari Rajah 5, jelaslah bahawa terdapat kesan CEJ pada hari tersebut kerana hasil penolakan komponen $\mathrm{H}$ di khatulistiwa dan luar khatulistiwa geomagnetik menghasilkan nilai negatif yang sangat tinggi. Kehadiran CEJ pada hari tersebut cenderung menyebabkan suar suria mengurangkan keamatan arus keseluruhan. Faktor kehadiran CEJ juga turut dilaporkan oleh Rastogi et al. (1999).

Pemerhatian turut dipanjangkan kepada data indeks Dst dan data fluks radio $10.7 \mathrm{~cm}$ seperti yang dikeluarkan oleh set data World Data Center for Geomagnetism (WDC), Kyoto dan NASA/OMNI GSFC seperti dalam Rajah 6 dan 7. Indeks Dst dianalisis untuk melihat sama ada berlaku ribut magnet berlaku atau tidak pada hari tersebut dan data F10.7 adalah untuk melihat kitaran suria. Tarikh dipilih adalah dari 1 hingga 11 Ogos 2011. Data indeks 


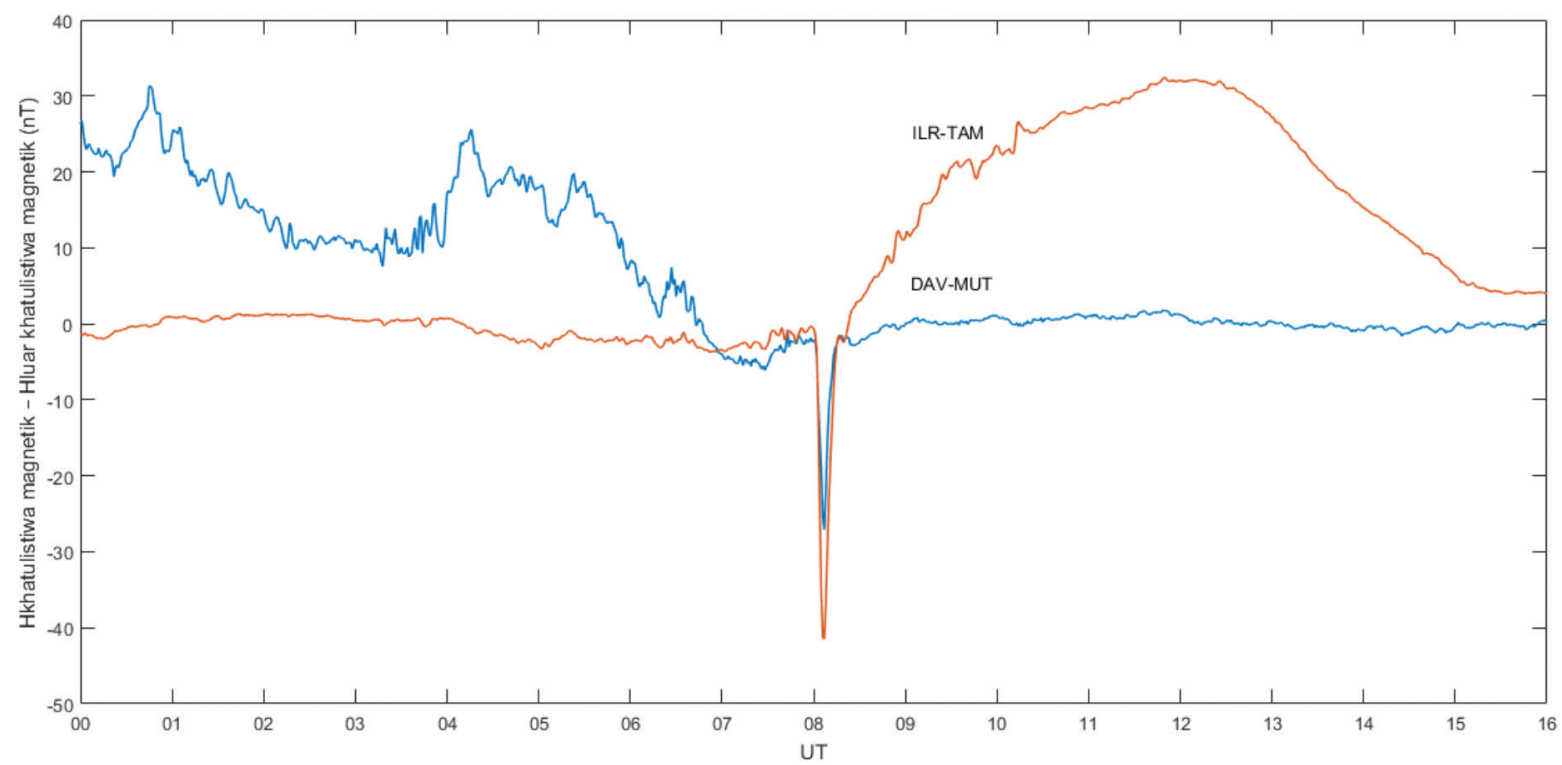

RAJAH 5. Hasil penolakan nilai komponen H dari stesen magnetik khatuistiwa dan luar magnetik khatulistiwa iaitu stesen DAV dengan MUT dan ILR dengan TAM

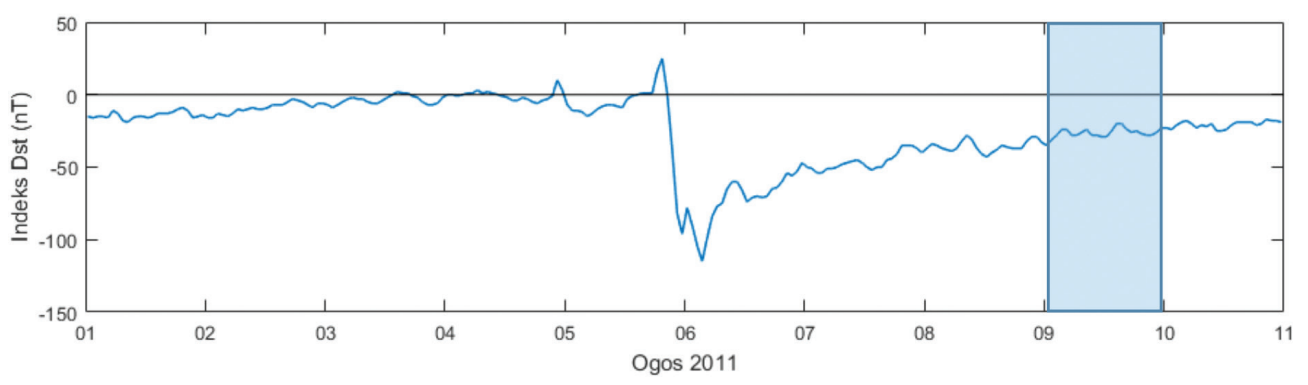

RAJAH 6. Nilai indeks Dst sepanjang 1 Ogos sehingga 11 Ogos. Kes kajian adalah pada 9 Ogos 2011 yang ditandakan dengan warna biru

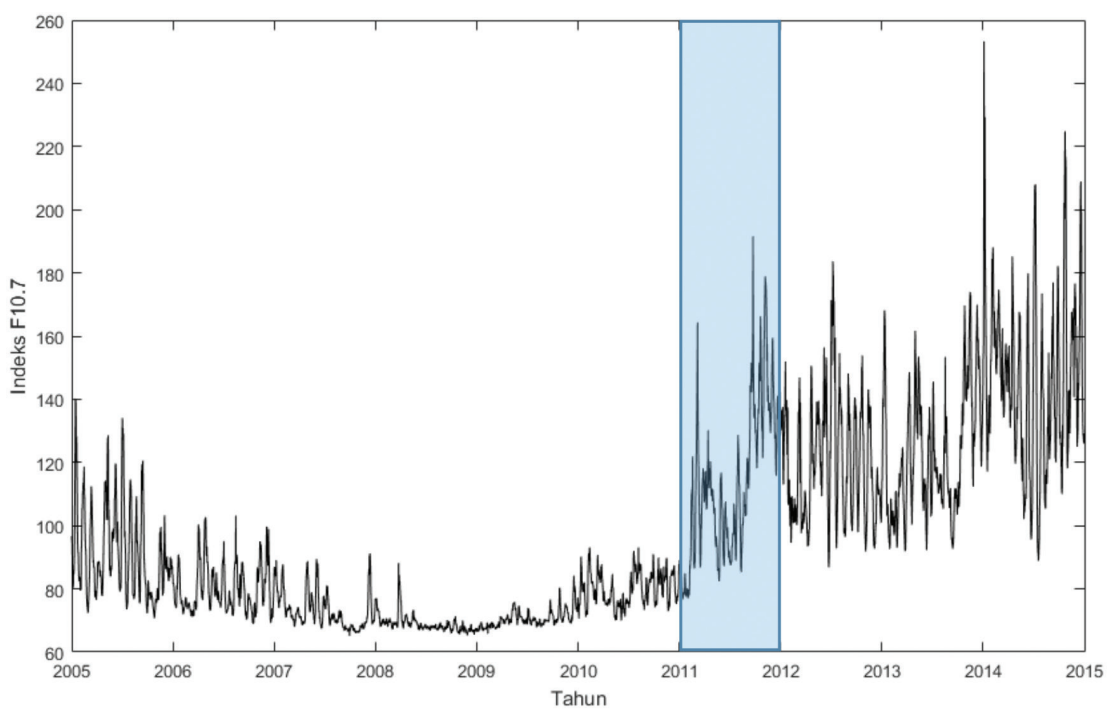

RAJAH 7. Kitaran suria berdasarkan indeks F10.7. Suar suria yang dikaji adalah pada fasa menaik kitaran suria ke-24. Tanda biru adalah tahun 2011 suar suria kelas X6.9 berlaku 
Dst menunjukkan berlaku ribut magnet pada 6 Ogos 2011 . Oleh itu, dapat disimpulkan bahawa pada tarikh kes kajian adalah pada tempoh fasa pemulihan dengan pengurangan arus di khatulistiwa turut boleh berlaku walaupun Rastogi (1997) mengatakan kes seperti ini kebanyakannya berlaku pada fasa permulaan ribut geomagnet. Berdasarkan Rajah 7, kes kajian pada tahun 2011 adalah pada fasa suria menaik. Kajian sebelum ini mendapati fenomena ini berlaku pada kitaran suria maksima (Yamazaki et al. 2009). Tambahan pula, kedudukan bumi turut diperihalkan untuk kes kajian ini iaitu pada soltis Jun. Tarikh kejadian iaitu pada bulan Ogos adalah selari dengan kajian oleh Yamazaki et al. (2009) yang turut melaporkan pengurangan keamatan komponen H berlaku pada soltis Jun. Natijahnya, pengurangan keamatan komponen $\mathrm{H}$ ini tidak bergantung kepada kitaran suria namun bergantung kepada kedudukan bumi mengelilingi matahari.

\section{KESIMPULAN}

Buat pertama kalinya kesan suar suria yang menyebabkan pengurangan keamatan arus ionosfera di pelbagai sektor longitud telah berjaya dilaporkan. Berdasarkan kajian ini, terdapat tiga kesimpulan mengenai ciri-ciri suar suria yang menyebabkan pengurangan arus ionosfera di kesemua longitud sektor yang dikaji. Pertama, suar suria tersebut adalah dari kelas $\mathrm{X}$ yang berlaku dalam kitaran suria menaik pada Jun soltis. Kedua, suar suria yang menyebabkan pengurangan keamatan arus ini didapati berlaku pada fasa pemulihan ribut suria. Akhir sekali, fenomena suar suria ini turut memberi sedikit kesan kepada stesen yang terletak di luar khatulistiwa geomagnetik. Kajian mengenai kesan suar suria ini boleh ditambah baik dengan menambah bilangan data daripada kawasan luar khatulistiwa magnetik. Keadaan arus ketika berlakunya suar suria pada tarikh 9 Ogos 2011 ini berpotensi untuk dimodelkan agar kajian terhadap arus ionosfera global dapat dijalankan.

\section{PENGHARGAAN}

Penulis berterima kasih kepada semua ahli projek MAGDAS atas kerjasama dan sumbangan yang diberikan dalam kajian ini. Sumber kewangan adalah ditaja oleh Universiti Kebangsaan Malaysia dan Kementerian Pelajaran Malaysia menggunakan geran FRGS/1/2015/ST02/UKM/02/1 dan GUP-2016-016. Data satelit GOES yang didapati melalui laman web https://www.ngdc.noaa.gov/stp/satellite/ goes/dataaccess.html. Pengarang mengakui penggunaan perkhidmatan NASA/GSFC OMNIWeb Space Physics Data Facility (atau CDAWeb atau ftp) dan data OMNI. Kami juga berterima kasih kepada WDC for Geomagnetism, Kyoto dan balai-balai cerap geomagnetik (Kakioka [JMA], Honolulu dan San Juan [USGS], Hermanus [RSA]), jaringan INTERMAGNET dan pihak lain yang terlibat dalam penghasilan indeks Dst.

\section{RUJUKAN}

Chapman, S. 1951. The equatorial electrojet as detected from the abnormal electric current distribution above Huacayo, Peru and elsewhere. Arch. Meteol. Geophys. Bioklimatol. 4(1): 368-390.

Hamid, N.S.A., Ismail, W.N.I. \& Yoshikawa, A. 2017. Latitudinal variation of ionospheric currents in southeast Asian sector. Advanced Science Letters 23(2): 1444-1447.

Hamid, N.S.A., Liu, H., Uozumi, T. \& Yoshikawa, A. 2015. Empirical model of equatorial electrojet based on groundbased magnetometer data during solar minimum in fall. Earth, Planets and Space 67: 205.

Hamid, N.S.A., Liu, H., Uozumi, T. \& Yumoto, K. 2013. Solar activity dependence of equatorial jet current in Southeast Asia region. Antarctic Record 57(3): 329-337.

Ismail, W.N.I., Hamid, N.S.A., Abdullah, M., Yoshikawa, A. \& Uozumi, T. 2017. Longitudinal variation of eej current during different phases of solar cycle. Journal of Physics: Conference Series 852, conference 1.

Nagata, T. 1952. Characteristics of the solar flare effect (Sqa) on geomagnetic field at Huancayo (Peru) and at Kakioka (Japan). Journal of Geophysical Research 57(1): 1-14.

Ning, B. \& Li, G. 2014. Evidence of daytime 150-km echoes associated with the upper $\mathrm{E}$ region density gradient over Sanya. In General Assembly and Scientific Symposium (URSI GASS), 2014 XXXIth URSI. pp. 1-1.

Okeke, F.N. 2006. A study of Sq (H) variations over equatorial electrojet regions. Journal of Physics 18(1): 45-52.

Onwumechili, C. 1997. The Equatorial Electrojet. Netherlands: Overseas Publishers Association. pp. 159-246.

Rabiu, A.B., Folarin, O.O., Uozumi, T., Hamid, N.S.A. \& Yoshikawa, A. 2017. Longitudinal variation of equatorial electrojet and the occurrence of its counter electrojet. Annales Geophysicae 35(3): 535-545.

Rastogi, R.G., Chandra, H. \& Yumoto, K. 2013. Unique examples of solar flare effects in geomagnetic $\mathrm{H}$ field during partial counter electrojet along CPMN longitude sector. Earth Planets Space 65: 1027-1040.

Rastogi, R.G., Deshpande, M.R. \& Sastri, N.S. 1975. Solar flare effect in equatorial counter electrojet currents. Nature 258: 218-219.

Rastogi, R.G. 1997. Midday reversal of equatorial ionospheric electric field. Annales Geophysicae 15: 1309-1315.

Rastogi, R.G., Pathan, B.M., Rao, D.R.K., Sastry, T.S. \& Sastri, J.H. 1999. Solar flare effects on the geomagnetic elements during normal and counter electrojet periods. Earth Planets Space 51: 947-957.

Sastri, J.H. 1975. The geomagnetic solar are of 6 July 1968 and its implications. Ann. Geophys. 31: 481-485.

Shojanoori, R., Shafri, H.Z.M., Mansor, S. \& Ismail, M.H. 2016. The use of worldview-2 satellite data in urban tree species mapping by object-based image analysis technique. Sains Malaysiana 45(7): 1025-1034.

Simon, N., de Roiste, M., Crozier, M. \& Rafek, A.G. 2017. Representing landslides as polygon (areal) or points? how different data types influence the accuracy of landslide susceptibility maps. Sains Malaysiana 46(1): 27-34.

Thomas, N., Vichare, G. \& Sinha,A.K. 2016. Spatial frequencies associated with the latitudinal structures of ionospheric currents seen by CHAMP satellite. Astrophysics and Space Science 361(7): 1-13. 
Yamazaki, Y., Yumoto, K., Yoshikawa, A., Watari, S. \& Utada, H. 2009. Characteristics of counter-Sq SFE (SFE*) at the dip equator CPMN stations. Journal of Geophysical Research 114: A05306.

Yamazaki, Y. \& Maute, A. 2016. Sq and EEJ - A review on the daily variation of the geomagnetic field caused by ionospheric dynamo currents. Space Sci Rev. 206(1-4): 299-405.

N.S.A. Hamid* \& N.M.N. Annadurai

Pusat Pengajian Fizik Gunaan

Fakulti Sains dan Teknologi

Universiti Kebangsaan Malaysia

43600 UKM Bangi, Selangor Darul Ehsan

Malaysia

\author{
A. Yoshikawa \\ Department of Earth and Planetary Sciences \\ Faculty of Sciences, 33 Kyushu University \\ 6-10-1 Hakozaki, Higashi-ku \\ Fukuoka 812-8581 \\ Japan
}

A. Yoshikawa

International Center for Space Weather Science and Education (ICSWSE)

Kyushu University 53

6-10-1 Hakozaki, Higashi-ku

Fukuoka 812-8581

Japan

*Pengarang untuk surat-menyurat; email: shazana.ukm@gmail. com

Diserahkan: 3 Ogos 2017

Diterima: 16 Oktober 2017 